ISSN : 2303-1514 | E-ISSN : 2598-5949

\title{
DEVELOPING FUN THINKERS BOOK LEARNING MEDIA ON THE TOPIC OF PERISTIWA ALAM YANG TERJADI DI INDONESIA AT GRADE V OF ELEMENTARY SCHOOL
}

\author{
Mariatul Kibtiah $^{1}$, Nana Hendracipta ${ }^{2}$ Encep Andriana $^{3}$ \\ 1,2,3 Universitas Sultan Ageng Tirtayasa, Indonesia \\ 'mariatul7kibtiah@gmail.com, ${ }^{2}$ nanahendracipta@untirta.ac.id, ${ }^{3}$ encepandriana@untirta.ac.id
}

\section{PENGEMBANGAN MEDIA PEMBELAJARAN FUN THINKERS BOOK MATERI PERISTIWA ALAM YANG TERJADI DI INDONESIA DI KELAS V SEKOLAH DASAR}

\begin{tabular}{|c|c|}
\hline ARTICLE HISTORY & ABSTRACT \\
\hline $\begin{array}{l}\text { Submitted: } \\
\text { 24 Desember } 2020 \\
24^{\text {th }} \text { December } 2020\end{array}$ & $\begin{array}{l}\text { Abstract: This research aimed to develop fun thinkers book learning media on the topic of "Peristiwa } \\
\text { alam yang terjadi di Indonesia" at grade } V \text { of elementary school and to know the feasibility of the } \\
\text { learning media. This research was research and development involving } 6 \text { steps: 1) problem analysis, 2) } \\
\text { data information collection, 3) product design, 4) design validation, 5) product revision, and 6) product } \\
\text { testing. The subject on this study were } 10 \text { students at grade V. The data were collected through } \\
\text { interviews, quistionaire, the validity from material experts, language experts, media experts, and a } \\
\text { quistionaire of students' response. The result of this research was fun thinkers book learning media } \\
\text { which consisted of two components: a book and the frame. The feasibility of the media was obtained } \\
\text { from the result of the assesment from the experts. They were media experts, material experts, language } \\
\text { experts, and quistionnaire of the students response with the average precentage of } 90.8 \% \text {, 97.5\%, } \\
81.82 \% \text {, and } 82.23 \% \text { respectively. Based on these results, it was concluded that fun thinkers book } \\
\text { learning media was feasible to be used as a learning media on the topic of "Peristiwa alam yang terjadi } \\
\text { di Indonesia". }\end{array}$ \\
\hline
\end{tabular}

Keywords: fun thinkers book, "peristiwa alam yang terjadi di Indonesia"

Accepted:

15 Juni 2021

$15^{\text {th }}$ June 2021

Published:

25 Agustus 2021

$25^{\text {th }}$ August 2021
Abstrak: Penelitian ini bertujuan untuk mendeskripsikan pengembangan media pembelajaran fun thinkers book materi peristiwa alam yang terjadi di Indonesia di kelas $v$ Sekolah Dasar dan mengetahui kelayakan media pembelajaran fun thinkers book materi peristiwa alam yang terjadi di Indonesia di kelas v Sekolah Dasar. Penelitian ini merupakan penelitian dan pengembangan (Research and Development) yang terdiri dari 6 langkah, yaitu: 1) analisis masalah, 2) mengumpulkan informasi data, 3) desain produk, 4) validasi desain, 5) revisi produk, 6) uji coba produk. Subjek dalam penelitian ini adalah 10 siswa kelas V SD. Data yang dikumpulkan dalam penelitian ini wawancara, angket validasi ahli materi, ahli bahasa, ahli media dan angket respon siswa. Hasil penelitian dari pengembangan ini berupa produk media pembelajaran fun thinkers book yang terdiri dari 2 komponen, yaitu komonpen buku dan komponen bingkai. Kelayakan media pembelajaran fun thinkers book didapat dari hasil penilaian tim ahli yaitu ahli media, ahli materi, ahli bahasa, dan angket respon siswa yang masing-masing memperoleh rata-rata skor presentase 90.8\%, 97.5\%, 81.82\%, dan $82.23 \%$. Berdasarkan hasil tersebut, dapat disimpulkan bahwa media pembelajaran fun thinkers book layak digunakan sebagai salah satu media pembelajaran materi peristiwa alam yang terjadi di Indonesia.

Kata Kunci: fun thinkers book, peristiwa alam yang terjadi di Indonesia

\section{CITATION}

Kibtiah, M., Hendracipta, N., \& Andriana, E. (2021). Developing Fun Thinkers Book Learning Media on the Topic of Peristiwa Alam Yang Terjadi di Indonesia at Grade V of Elementary School. Primary: Jurnal Pendidikan Guru Sekolah Dasar, 10 (4), 829-835. DOI http://dx.doi.org/10.33578/jpfkip.v10i4.8144. 


\section{PENDAHULUAN}

Manusia tidak lepas dari pendidikan, sebagai makhluk Tuhan yang diberikan akal dan pikiran, manusia dalam menerapkan akal dan pikiran mereka dibutuhkan arahan dan tujuan untuk kehidupannya. Sebagai salah satu hasil dari pendidikan tersebut adalah manusia belajar untuk menjadi pribadi yang lebih baik lagi. Melalui pembelajaran tersebut manusia dari yang tidak tahu tentang sesuatu hal menjadi tahu. Pendidikan dapat kita dapatkan melalui pembelajaran di sekolah. Salah satu mata pelajaran yang dapat memberikan pengalaman belajar yaitu mata pelajaran IPA. Pendapat (Maulana, dkk, 2015: 242) mengartikan IPA adalah upaya untuk mengubah pengalaman menjadi suatu pemikiran logis atau pemikiran ilmiah. Melalui pembelajaran yang sistematis dengan berbagai metode dan penggunaan media yang didukung dengan berbagai teori untuk memecahkan suatu masalah sehingga mendapatkan suatu pengetahuan baru.

Salah satu penunjang segala manfaat atau tujuan dari pembelajaran IPA atau sains yaitu diperlukan suatu media pembelajaran. Seperti yang kita ketahui media pembelajaran merupakan alat atau perantara untuk menyampaikan materi pembelajaran yang dapat merangsang keingintahuan siswa. Gerlach dan Ely (Sanjaya, 2012: 204) memandang media pembelajaran tidak hanya berupa alat dan bahan saja, tetapi juga memungkinkan siswa dapat memperoleh pengetahuan. Menurut Gerlach secara umum media (pembelajaran) itu meliputi orang, bahan, peralatan, atau kegiatan yang menciptakan kondisi yang memungkinkan siswa memperoleh pengetahuan, keterampilan, dan sikap.

Berdasarkan observasi dan wawancara yang dilaksanakan di kelas V A SD Negeri Kragilan 2, guru sudah menggunakan media pembelajaran dalam pembelajaran IPA. Namun beliau mengatakan memerlukan media pembelajaran IPA yang dapat melibatkan siswa secara aktif dan menyeluruh, serta membantu siswa dalam memahami materi yang diajarkan. Beliau berkata karena jumlah siswa yang banyak dalam satu kelas sedikit kesulitan dalam menggunakan media sehingga akan membuat belajar tidak kondusif. Beliau lebih sering memanfaatkan media yang sudah ada seperti buku LKS atau buku paket. Padahal peserta didik seusia SD tertarik dengan hal-hal baru contohnya dengan media pembelajaran yang melibatkan siswa dalam penggunaannya. Media pembelajaran yang menarik dapat memusatkan perhatian siswa, memotivasi siswa, dan menimbulkan rasa semangat untuk mempelajari materi tersebut. Terlebih jika media tersebut menarik jika dilihat, mempunyai bentuk yang unik serta mempunyai warna yang menarik.

Manfaat media pembelajaran dikemukakan oleh Sudjana \& Rivai (Arsyad, 2003: 24) yang mengemukakan manfaat media pembelajaran dalam proses belajar siswa, yaitu: (1) Pembelajaran akan lebih menarik perhatian siswa sehingga dapat menumbuhkan motivasi belajar, (2) Materi pembelajaran akan memiliki makna yang lebih jelas sehingga siswa dapat lebih memahaminya dan memungkinnya untuk menguasai dan mencapai tujuan pembelajaran. (3) Metode mengajar akan lebih bervariasi, tidak semata-mata komunikasi verbal melalui penuturan kata-kata oleh guru, sehingga siswa tidak bosan dan guru tidak kehabisan tenaga, apalagi kalau guru mengajar pada setiap jam pelajaran. (4) Siswa dapat lebih banyak melakukan kegiatan belajar sebab tidak hanya mendengarkan uraian guru, tetapi juga aktivitas lain seperti mengamati, melakukan ,mendemonstrasikan, memerankan, dan lain-lain.

Media Fun Thinkers Book materi peristiwa alam yang terjadi di Indonesia di kelas $\mathrm{V}$ sekolah dasar adalah pengembangan dari media pembelajaran yang disediakan dan dibuat oleh perusahaan khusus alat peraga pendidikan. Media pembelajaran Fun Thinkers menurut Gordon dalam Kurniawati (2017:656) adalah seperangkat buku yang dikemas untuk menciptakan kegiatan belajar menjadi lebih menyenangkan. yang menarik dan memotivasi siswa untuk mempelajari materi yang diajarkan serta dapat mengaktifkan siswa dalam proses pembelajaran. Media Fun Thinkers Book mempunyai bentuk seperti buku, media tersebut terdapat beberapa pertanyaan yang dapat melatih dan mengetahui sejauh mana siswa 
memahami pelajaran. Buku ini didesain dengan semenarik mungkin dengan warna, gambar dan cara penggunaan yang tidak biasa. Siswa selain belajar dengan menjawab pertanyaan juga sambil bermain seperti quis dengan memindahkan kotakkotak persegi pada jawaban bukan dengan menuliskannya, sehingga siswa akan lebih tertarik dalam menjawabnya. Siswa diajak untuk berpikir dalam menjawab pertanyaan tetapi dengan cara menyenangkan seperti bermain yaitu dengan memindahkan kotak-kotak persegi ke jawaban yang benar bukan dengan cara menuliskannya. Fun Thinkers Book dilengkapi dengan gambargambar yang berhubungan dengan materi sehingga siswa dapat mengetahui berbagai contoh peristiwa alam tanpa harus menunggu datangnya peristiwa alam tersebut.

Berdasarkan pemaparan permasalahan diatas oleh karena itu peneliti membuat penelitian yang bertujuan untuk mengetahui pengembangan media pembelajaran Fun Thinkers Book, kelayakan media fun thinkers book dan respon siswa terhadap media pembelajaran Fun Thinnkers Book materi peristiwa alam yang terjadi di Indonesia di kelas V-A SD Negeri Kragilan 2. Maka penelitian ini berjudul "Pengembangan Media Pembelajaran Fun Thinkers Book Materi Peristiwa alam di Indonesia pada Mata Pelajaran IPA Kelas V Sekolah Dasar".

\section{METODE PENELITIAN}

Bagian metode penelitian yang digunakan adalah metode penelitian dan pengembangan atau Research and Development (R\&D) yaitu metode penelitian yang digunakan untuk menghasilkan produk tertentu dan menguji kefektifan produk tersebut sehingga dapat befungsi di masyarakat luas (Sugiyono, 2010:407). (Sukmadinata, 2013:164) Penelitian dan pengembangan adalah suatu proses atau langkah pengembangan yang sudah ada, yang dapat dipertanggungjawabkan.

Berdasarkan pendapat diatas dapat disimpulkan bahwa penelitian dan pengembangan merupakan suatu proses yang digunakan untuk mengembangkan produk yang sudah ada sebelumnya atau menghasilkan produk yang dapat dipertanggungjawabkan dan digunakan di masyarakat luas. Dalam penelitian dan pengembangan ini, peneliti menghasilkan produk berupa media pembelajaran Fun Thinkers Book. Adapun desain Fun Thinkers Book menggunakan aplikasi corel draw dan cara menguji kelayakan dengan cara uji ahli dan uji terbatas. Tujuan dari penelitian pengembangan Fun Thinkers Book ini ialah untuk menghasilkan suatu produk yang dapat dimanfaatkan dalam proses pembelajaran, sehingga memiliki nilai manfaat dalam dunia pendidikan. Penelitian pengembangan yang akan dilakukan ini merujuk pada desain pengembangan yang dilakukan oleh Borg and Gall yang meliputi

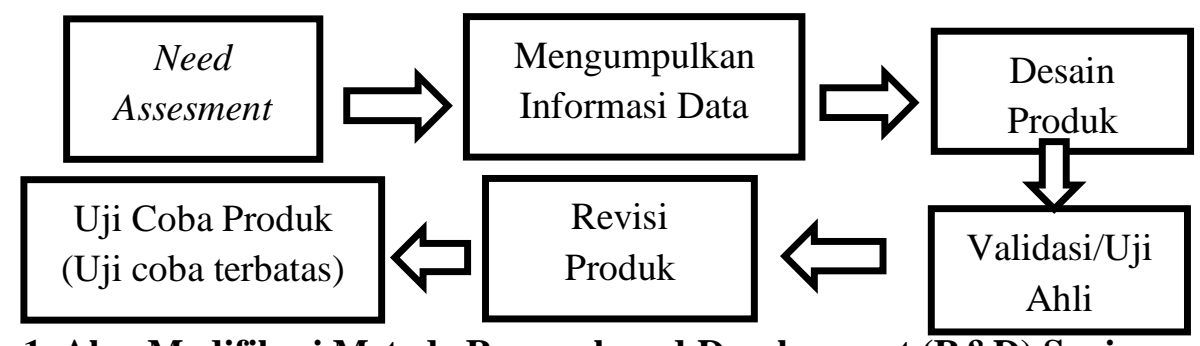

Gambar 1. Alur Modifikasi Metode Research and Development (R\&D) Sugiyono (2016:298)

Gambar di atas menjelaskan prosedur yang dilaksanakan dalam mengembangkan media Fun Thinkers Book. Berdasarkan gambar tersebut, langkah-langkah yang peneliti terapkan untuk pengembangan media Fun Thinkers Book dibatasi sampai 6 tahapan yaitu analisis masalah, pengumpulan data, desain produk, validasi desain, revisi desain, dan uji coba produk. Populasi pada uji coba produk adalah seluruh siswa kelas V A di SDN Kragilan 2 sebanyak 45 siswa dan sampel yang digunakan sebanyak 10 siswa kelas $\mathrm{V} \mathrm{A}$. Uji coba produk dilaksanakan secara langsung di sekolah untuk menetahui bagaimana respon siswa terhadap media pembelajaran Fun Thinkers Book 
materi peristiwa alam yang terjadi di Indonesia.

Teknik pengumpulan data dalam penelitian ini adalah menggunakan observasi, wawancara, dan dokumentasi. Dalam penelitian ini, wawancara dilakukan kepada guru kelas V A SD Negeri Kragilan 2, untuk mencari data mengenai informsi-informasi yang lebih mendalam mengenai permasalahan yang ada pada pengembanan media pembelajaran di sekolah dasar. Peneliti. Memilih wawancara tidak terstruktur, dimana guru bebas mengeluarkan pendapat tenang pertanyaan yang diajukan oleh peneliti. Sedangkan angket digunakan untuk mengetahui kelayakan produk dalam pengembangan media pembelajaran yan diperoleh dari hasil penilaian para ahli yang terlibat seperti, ahli media, ahli materi, ahli bahasa, dan subjek uji coba lapangan.

Instrumen yang dilakukan untuk mengumpulkan data pada penelitian ini, yaitu 1) wawancara guru kelas V A SDN Kragilann 2, 2) angket validasi untuk mengukur kelayakan media Fun Thinkers Book, 3) angket respon siswa untuk mengetahui tanggapan siswa terhadap media pembelajaran Fun Thinkers Book. Indikator dalam penelitian ini adalah terselesaikannya pengembangan media pembelajaran Fun Thinkers Book. Media pembelajaran ini dikatakan selesai apabila telah melalui enam tahap penelitian pengembangan menurut desain Borg and Gall yang dimodifikasi oleh Sugiyono yang terdiri atas analisis masalah, mengumpulkan informasi/data, desain produk, validasi/uji ahli, revisi produk, dan uji coba produk (uji coba terbatas).. Adapun kriteria kerberhasilannya yaitu: penilaian validasi ahli minimal dapat dinyatakan dengan kategori layak yaitu $61 \%-80 \%$ serta mendapat respon siswa dengan kategori minimal baik yaitu $61 \%$ $80 \%$.

Berikut ini tabel yang digunakan untuk mengetahui kelayakan pada media:

Tabel 1. Kriteria Kelayakan Media

\begin{tabular}{cc}
\hline Presentasi Pencapaian & Kategori Kelayakan \\
\hline $0 \%-20 \%$ & Tidak Layak \\
$21 \%-40 \%$ & Kurang Layak \\
$41 \%-60 \%$ & Cukup Layak \\
$61 \%-80 \%$ & Layak \\
$81 \%-100 \%$ & Sangat Layak \\
\hline
\end{tabular}

(Sumber: Modifikasi Purwanto, 2013:103)

\section{HASIL DAN PEMBAHASAN}

Penelitian ini dilaksanakan di SD Negeri Kragilan pada tanggal 12 Oktober 2020 sampai 12 Desember 2020. Hasil penelitian pada pengembangan media Fun Thinkers Book ini mengacu pada langkah-langkah pengembangan menurut Borg and Gall yang telah dimodifikasi oleh Sugiyono yaitu melakukan analisis masalah, pengumpulan data, desain produk, validasi produk, revisi produk, dan uji coba produk.

Tahapan pertama dalam penelitian ini yaitu melakukan analisis masalah yaitu dari permasalahan yang ada di Kelas V A SD Negeri Kragilan 2 yaitu kegitan pembelajaran sudah menggunakan media pembelajaran namun media pembelajaran tersebut masih terfokus pada guru seperti penggunaan buku paket atau LKS dan pengunaan media yang sudah ada saja sehingga siswa kurang aktif dalam kegiatan pembelajaran, terutama dalam pembelajaran IPA. Selanjutnya dilakukan tahap pengumpulan data. Peneliti melakukan pengumpulan data berupa studi literatur dengan menganalisis kebutuhan dan analisis materi. Pada analisis kebutuhan penliti melakukan wawancara tidak terstruktur kepada wali kelas V A SD Negeri Kragilan 2 terkaitdengan kegiatan pembelajaran IPA. Beliau mengatakan bahwa pembelajaran memerlukan media yangdapat melibatkan semua siswa aar siswa aktif dalam kegiatan pembelajaran.

Produk yang dikembangkan berupa media pembelajaran Fun Thinkers Book yang dirancang 
ISSN : 2303-1514 | E-ISSN : 2598-5949

seperti buku dengan bingkai peraga di dalamnya. Media Fun Thinkers Book ini terdiri dari dua bagian yaitu bagian buku dan bagian bingkai peraga yang dilengkapi dengan papan ubin sebanyak sembilan buah sebagai alat mencocokan pertanyaan dengan jawaban pada bagian kuis didalam buku Fun Thinkers Book. Media pembelajaran ini memuat materi peritiwa alam yang terjadi di Indonesia di kelas V sekolah dasar.

Tahap selanjutnya yaitu tahap validasi (uji ahli) kepada tim ahli validasi yang telah ditetapkan. Tahap ini bertujuan untuk memperoleh kritik, saran, dan masukan dari pihak yang menguji media Fun Thinkers Book yang telah dikembangkan. Setalah melalui tahap validasi tahap selanjutnya yaitu tahap revisi produk berdasarkan kritik, saran dan masukan dari tim ahli.

Mengingat kondisi saat ini yang sedang menghadapi pandemi Virus Corona masyarakat dianjurkan untuk tidak berkerumun di suatu tempat termasuk kegiatan belajar. Oleh karena itu penelitian ini hanya menggunakan 10 orang siswa dalam uji coba terbatas di SD Negeri Kragilan 2 dengan tetap mematuhi protokol kesehatan. Berikut adalah hasil perolehan persentase nilai kelayakan media Fun Thinkers Book dari tim ahli dan persentase hasil respon siswa.

Tabel 2. Hasil Validasi Ahli Media

\begin{tabular}{ccc}
\hline Aspek Penilaian & Ahli Media I & Ahli Media II \\
\hline Komunikasi Visual & 66 & 76 \\
Rekayasa Media & 10 & 10 \\
Kelayakan Isi & 16 & 20 \\
Mutu Teknis & 15 & 14 \\
Jumlah & & $\mathbf{2 2 7}$ \\
Persentase Nilai \% & $\mathbf{9 0 . 8 \%}$ & \\
Kriteria Kelayakan & Sangat Layak \\
\hline
\end{tabular}

Tabel 3. Hasil Validasi Ahli Materi

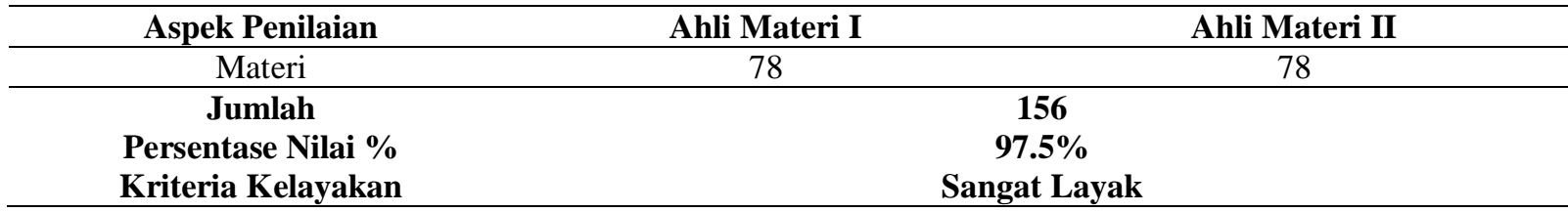

Tabel 4. Hasil Validasi Bahasa

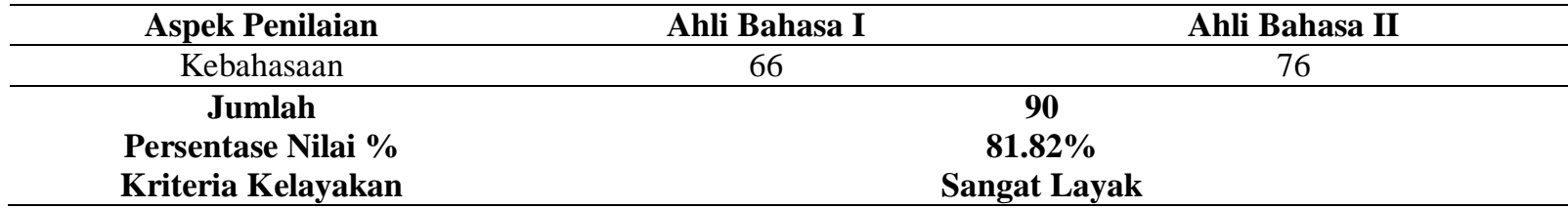

Tabel 5. Hasil Respon Siswa

\begin{tabular}{cc}
\hline Aspek Penilaian & Ahli Media I \\
\hline Tampilan & 66 \\
Ketertarikam & 10 \\
Kemanfaatan & 16 \\
\hline Jumlah & $\mathbf{6 9 9}$ \\
Persentase Nilai \% & $\mathbf{8 2 . 2 3 \%}$ \\
Kategori & Sangat Baik \\
\hline
\end{tabular}


Berdasarkan tabel diatas menunjukkan hasil penggabungan kedua tim ahli media memperoleh persentase sebesar $90.8 \%$ dengan kategori Sangat Layak. Tim ahli media mengatakan bahwa media Fun Thinkers Book sesuai dengan karakteristik siswa, dan menarik serta dapat memotivasi siswa dalam kegiatan pembelajaran. Hal tersebuat sesuai dengan pendapat (Indriana, 2011: 28-31) penentuan tepat tidaknya media salah satunya yaitu kesesuaian media dengan karakteristik siswa, pendidik harus mengenal karakteristik siswa agar bisa disesuaikan dengan media pembelajaran yang akan digunakan.

Adapun kekurangan dalam media yaitu penggunaan gambar peristiwa alam dalam buku Fun Thinkers Book sebaiknya menggunakan gambar realistis atau konkrit. Hal ini sesuai dengan yang dikemukakan (Asnawir \& Usman, 2002: 47) gambar merupakan alat visual paling efektif karena dapat divisualisasikan sesuatu yang akan dijelaskan dengan konkrit dan realistis. Informasi yang disampaikan dapat dimengerti dengan mudah karena hasil diraakan lebih mendekati kenyataan melalui foto yang diperlihatkan kepada anak-anak dan hasil yang diterima anak-anak.

Penilaian selanjutnya yaitu perolehan nilai dari penggabungan kedua tim ahli materi berdasarkan tabel memperoleh persentase sebesar 97.5\% dengan kategori Sangat Layak. tim ahli materi mengatakan konten materi sudah baik namun masih ada beberapa kekuarangan penggunaan gambar ilustrasi pada buku Fun Thinkers Book sebaiknya diganti dengan gambar real atau nyata yang terjadi seperti peristiwa alam di daerah kita. Hal ini didukung oleh pendapat yang dikemukakan (Sadiman, 2009:33) gambar yang baik untuk media pembelajaran harus bersifat autentik artinya gambar tersebut melukiskan situasi seperti ketika melihat benda yang sebenarnya. Pembelajaran dengan menggunakan bahan materi yang terdapat pada kehidupan siswa sehari-hari sehinga siswa dapat menerapkannya pada kehidupan mereka.

Penilaiannya terakhir yaitu perolehan nilai dari penggabungan kedua tim ahli bahasa berdasarkan tabel memperoleh persentase nilai sebesar $81.82 \%$ dengan kategori Sangat Layak. Namun, media Fun Thinkers Book masih memiliki kekurangan yaitu penggunaan bahasa harus lebih sesuai dengan PUEBI (Pedoman Umum Ejaan Bahasa Indonesia) dan penambahan glosarium pada buku Fun Thinkers Book. PUEBI adalah bagian dari ejaan. Hal ini sesuai dengan yang dikemukakan (Sriyanto, 2014: 6) Ejaan adalah kaidah bahasa Indonesia meliputi tata bunyi, tata bentuk kata, tata kalimat dan tata tulis. Artinya dalam penggunaan bahasa harus sesuai dengan kaidah bahasa Indonesia atau Ejaan. Selain itu, penambahan glosarium pada media Fun Thinkers Book untuk mempermudah siswa dalam menemukan arti dari kata-kata tertentu. Hal ini sesuai dengan penggertian glosarium menurut KBBI, yaitu daftar kata dengan penjelasannya dalam bidang tertentu.

Tahap selanjutnya setelah melaksanakan uji validasi tim ahli yaitu melakukan revisi sesuai dengan kritik dan saran yang diberikan oleh tim ahli. Setelah di revisi selanjutnya media Fun Thinkers Book diuji cobakan (uji coba terbatas) pada 10 orang siswa kelas V A SD Negeri Kragilan 2. Berdasarkan tabel media Fun Thinkers Book memproleh respon dengan rerata skor sebesar $82,23 \%$ dengan kategori Sangat Baik. pada saat melakukan uji coba siswa terlihat antusias dan tertarik menggunakan media pembelajaran Fun Thinkers Book. Siswa berkelompok berdiskusi secara fokus dan aktif terhadap apa yang harus dikerjakan sesuai dengan petunjuk pada buku Fun Thinkers Book. Pembelajaran terlihat menjadi interaktif karena siswa salin berinteraksi dalam menemukan jawaban yang tepat pada bagian mencocokkan pertanyaan dengan jawaban menggunakan bingkai peraga pada buku Fun Thinkers Book tersebut. Groiler Fun Thinkers Book dirancan dengan pelajaran dalam format yan menarik mirip sebuah permainan. Lebih lanjut Fun Thinkers Book adalah media pembelajaran interaktif yang dirancang untuk merangsang keuatan otak anak serta mendorong perkembangan intelektual anak.

Berdasarkan hasil penelitian pengembangan media pembelajaran Fun Thinkers 
Book layak diuji cobakan di lapangan. Dengan media pembelajaran Fun Thinkers Book dapat membantu guru dalam proses mengajar dan untuk siswa agar lebih aktif dalam kegiatan pembelajaran serta siswa dapat lebih termotivasi dalam mempelajari materi peristiwa alam yang terjadi di Indonesia. Sehingga pembelajaran dalam kelas menjadi lebih interaktif.

\section{SIMPULAN DAN REKOMENDASI}

Berdasarkan hasil penelitian yang telah dijelaskan pada pembahasan maka dapat ditarik kesimpulan bahwa media Fun Thinkers Book yang dikembangkan ini berdasarkan hasil validasi dengan memperoleh nilai $90.8 \%$ dari ahli media, $97.5 \%$ dari ahli materi, $81.82 \%$ dari ahli bahasa, dan $82.23 \%$ dari respon siswa dengan kategori Sangat Layak. Penggunaan media Fun Thinkers Book materi peristiwa alam yang terjadi di Indoensia di kelas $\mathrm{v}$ ini dinilai sangat layak digunakan dan menarik serta dapat membuat pembelajaran lebih interaktif.

Adapun peneliti memberikan saran untuk meningkatkan kualitas media pembelajaran, di antaranya: (1) Hal-hal yang harus diperhatikan dalam mengembangkan media pembelajaran Fun Thinkers book ini adalah pemilihan materi, ketelitian dalam penulisan bahasa sesuai dengan PUEBI (Pedoman Umum Ejaan Bahasa Indonesia), penggunaan gambar, isi/materi harus dibuat lebih menarik, sehingga dapat menghasilkan media pembelajaran Fun Thinkers Book lebih maksimal dan lebih layak digunakan anak sekolah dasar. (2) Media pembelajaran Fun Thinkers Book perlu dikembangkan pada mata pembelajaran IPA materi yang lain dan materi pada mata pelajaran lain untuk menambah ketersediaan media pembelajaran dalam membantu pembelajaran di sekolah.

\section{DAFTAR PUSTAKA}

Anonim. (2020). Grolier Fun Thinkers Book. Diakses melalui grolier-asia.com/ourproducts/fun-thinkers/.
Arsyad, A. (2003). Media Pembelajaran. Jakarta: PT. Raja Grafindo Persada.

Asnawir, dan Usman. (2002). Media Pembelajaran. Jakarta: Diputat Pers.

Glosarium, (Def. 2) (n.d). Dalam Kamus Besar Bahasa Indonesia (KBBI) Online. Diakses melalui https://kbbi.web.id/glosarium.

Indriana, D. (2011). Ragam Alat Bantu Media Pengajaran. Jogjakarta: Diva Press.

Kurniawati, E, S. (2017). Pengaruh Media Fun Thinkers Terhadap Penguasaan Kosakata Bahasa Inggris Anak Tunarungu Kelas VII SMPLB-B di Slb Wiyata Dharma 1 Sleman, Jurnal Widia Ortodidaktika. 6: 654-656.

Maulana, dkk. (2015). Ragam Model Pembelajaran di Sekolah Dasar. Sumedang: UPI Sumedang Press.

Purwanto, N. (2013). Prinsip-Prinsip dan Teknik Evaluasi Pembelajaran. Bandung: PT. Remaja Rosdakarya.

Sadiman, A, S, dkk. (2009). Media Pendidikan. Jakarta: Raja Grafindo Persada.

Sanjaya, W. (2012) Media Komunikasi Pembelajaran. Jakarta: Kencana Prenada Media Group.

Sriyanto. (2014). Seri Penyuluhan Bahasa Indonesia: Ejaan. Diakses melalui badanbahasa.kemendikbud.go.id.

Sugiyono. (2010). Metode Penelitian Pendekatan Kuantitatif, Kualitatif, dan $R \& D$. Bandung: Alfabeta.

Sugiyono. (2016). Metode Penelitian Kuantitatif, Kualitatif, dan $R \& D$. Bandung: Alfabeta.

Sukmadinata, N, S. (2013). Metode Penelitian Pendidikan. Bandung: PT Remaja Rosdakarya. 